\title{
Smart for development: Income level as the element of smartphone diffusion
}

\author{
Maral Jamalova ${ }^{a^{*}}$, and Milán György Constantinovits ${ }^{a}$
}

${ }^{a}$ Szent István University, Gödöllö, Hungary

\begin{tabular}{l}
\hline C H R O N I C L E \\
\hline Article history: \\
Received: July 42019 \\
Received in revised format: Sep- \\
tember 142019 \\
Accepted: October 29, 2019 \\
Available online: \\
October 29, 2019 \\
\hline Keywords: \\
Smartphone market \\
Segmentation \\
Smartphone diffusion \\
Income
\end{tabular}

\section{A B S T R A C T}

\begin{abstract}
For understanding the place of income in smartphone diffusion, this paper aims to find out the dependence of smartphone market indicators on income level worldwide and in the developing economies. The strength of the relationship between above-mentioned variables identifies the speed of smartphone diffusion influenced by income. For current purposes, secondary data from 189 countries were analyzed by using Hierarchical Cluster Analysis and Chi-square analysis. The results confirmed that income level influences smartphone purchase and diffusion. However, the strength of the relationship between income and smartphone market indicators is diverse globally and in developing countries. In developing countries, the strength of the relationship is smaller in comparison with the overall results. It means that income level has weak moderating effect in smartphone diffusion, and it cannot be considered as a key indicator of smartphone diffusion in developing countries according to results of the analysis in 2016 and the arithmetic mean of 2013-2017 years.
\end{abstract}

(C) 2020 by the authors; licensee Growing Science, Canada

\section{Introduction}

Nowadays, the smartphone industry and telecommunication infrastructure are among the fastest growing fields in the world. According to the website of the International Telecommunication Union (ITU, specialized agency of the UN), penetration rate increased from 4 people (per 100 inhabitants) in 2007 to 69.3 in 2018 (ITU, 2018). Also, in 2018, the number of active mobile-broadband subscriptions (simply, wireless access to the Internet) reached 5.3 billion. Interestingly, the main reason for the growth and prosperity of the industry is based on the increase in the penetration rate in developing countries. The quantity of mobile-cellular phone subscriptions in developing countries steadily increase year by year. According to ITU, in 2018, main drivers of the growth in wireless Internet access are African, Asian and Arab countries. In the smartphone industry, pace of the adaption is high in comparison with the other fields of industries. In order to avoid confusion, it is better to separate smartphones from basic mobile phones and feature phones. Basic mobile phones are designed for calls and short messages, and also for some simple features as calendar, alarm and so on (Persaud \& Azhar, 2012). While the users of feature phones take advantage of Internet browsing and e-mail sending/receiving features, yet it is not a smartphone (Groß, 2015). Smartphones are the result of product development in the mobile phone industry (Haskell, 2004), and the first model was introduced by Steve Jobs in 2007. In order to avoid confusion with feature phones, we are going to involve newer researches which are exactly focused on smartphones and/or smartphone market. Global System for Mobile Communications (GSMA) published annual "The Mobile Economy" report in 2019 and indicated mobile penetration and smartphone ownership numbers in different regions of the world in 2018. Numbers were indicated as follows (GSMA Intelligence, 2019): the highest penetrated region of the world was Europe, where $85 \%$ of people used mobile services and smartphone adoption was $72 \%$ in 2018. In the mentioned report North America was in second place with $83 \%$ penetration rate where $80 \%$ of the population used smartphones. Commonwealth Independent States (CIS) almost reached the level of the above-mentioned developed

* Corresponding author.

E-mail address: mjamalova@hotmail.com (M. Jamalova) 
regions. Mobile service diffusion was $80 \%$, and smartphones were accepted by $53 \%$ of inhabitants. Latin America (LA) and the Asia Pacific (AP) had almost the same diffusion rate (67\% and 66\%). However, smartphone adoption in LA is significantly higher (65\%) than in AP (54\%). The Middle East and North Africa (MENA) showed lower values in comparison with other regions on mobile penetration and smartphone adoption, $64 \%$, and 52\% respectively. However, the lowest output resulted in the weak economies of Sub-Saharan Africa (SSA). The penetration rate in the region was $45 \%$ while the diffusion of smartphones was particularly low (36\%). All over the world, subscriber penetration was $67 \%$ and smartphone adoption was $60 \%$ in 2018 . Income is one of the main elements of the decision-making process. High income creates the opportunity to purchase products with better quality and changes the preference of consumers. The influence of income on buying decision can be supported by the acquisition of middle or expensive priced products. Smartphones are easily considered as key products which are affected by income (Puspitasari \& Ishii, 2016; Reid, 2018). In the USA around 30\% of adults with low-income did not have smartphones in 2017 (Reid, 2018). Moreover, smartphones became a fashion/status accessory and it is costly to use it (Reid, 2018, p. 46). The results of the other survey conducted in Jordan showed that individually price is important for smartphone buyers, however, there is no statistically significant relationship between price and smartphone purchase (Mohammed, 2018). Also, nowadays, smartphones are not so expensive as it was supposed to be several years ago (IDC, 2017). After 2011, the price of Android smartphones dropped significantly (Table 1.). A growing number of manufacturers and intense competition also had an impact on the average price of the devices.

Table 1

The average selling price of smartphones by the operating system

\begin{tabular}{|c|c|c|c|c|c|c|c|c|c|c|}
\hline Year & 2007 & 2008 & 2009 & 2010 & 2011 & 2012 & 2013 & 2014 & 2015 & 2016 \\
\hline Average Selling Price of iOS (Apple) & $\$ 594$ & $\$ 621$ & $\$ 623$ & $\$ 703$ & $\$ 712$ & $\$ 686$ & $\$ 669$ & $\$ 680$ & $\$ 716$ & $\$ 690$ \\
\hline Average Selling Price of Android (Google) & - & $\$ 403$ & $\$ 435$ & $\$ 441$ & $\$ 380$ & $\$ 318$ & $\$ 272$ & $\$ 237$ & $\$ 217$ & $\$ 214$ \\
\hline
\end{tabular}

Source: IDC Worldwide Mobile Phone Tracker (2017)

In emerging countries mobile phone diffusion depends on income and/or price of the handset (James, 2016). Consumers from developing countries are price sensitive in the case of smartphone purchase (Liao \& Hsieh, 2013). Also, price sensitivity can differ according to geography (Abdel-Wahab \& El-Masry, 2011; Donner \& Jonathan, 2009). Nowadays, the price of the cheapest smartphones fluctuates around $120 \$$ and it is not the appropriate price for the consumers for the third world countries. For instance, according to the prognosis of GSMA, the average price of smartphones is expected to drop up to $109 \$$ in Kenya and 97\$ in India in 2020 (GSMA, 2017). However, it is evident that the poorest consumers from Sub-Saharan Africa and other parts of the world who earn only $5 \$$ per day cannot afford these devices. The paper focuses on identifying the importance of income level in smartphone adoption and overall smartphone diffusion process. In the first stage, countries clustered using hierarchical clustering method based on three variables: mobile cellular subscription, iOS market share and Android market share. In the next stage, the output of the cluster analysis will be used as a dependent variable of Chi-square analysis. In current paper, the income level of the countries is considered to be the independent variable and strength of the relationship will define the adoption (diffusion) speed. Moreover, this paper considers the diffusion term only from the purchase context.

\section{Literature review}

\subsection{Consumer Behavior in the Smartphone Market}

First and foremost, researchers were interested in analyzing smartphone purchase behavior at macro level in different countries such as purchase behavior in Turkey (Karakaş \& Öztürk, 2016), Australia (Roach, 2009), Bangladesh (Uddin et al., 2014), Malaysia (Shabrin et al., 2017) and other countries in the world. Moreover, they investigated the level of influence of different factors such as private level brands (Coelho et al., 2013), physical attributes (Uddin et al., 2014), economic inequalities (Potnis, 2016), brand image and product attributes (Ann et al., 2017) on consumer behavior. Purchase of smartphone is a complex decision which is influenced by technical (Bringula et al., 2018), social (Hooi Ting et al., 2011) and economic factors (for example price, monthly income (Bringula et al., 2018)). The relationship between socio-economic indicators and smartphone vendors' market share have been already proved in developed and developing countries (Jamalova \& Constantinovits, 2019). Comprehensive researches regarding the effect of mobile phones/smartphones on economic growth are from 2008 (World Bank, 2008), 2011 (Abdel-Wahab \& El-Masry, 2011), and 2016 (James, 2016). James (2016) in the book called "The Impact of Mobile Phones on Poverty and Inequality in Developing Countries" used GNI and mobile cellular phone subscriptions in order to identify diffusion trends and problems in mobile phone market in the underdeveloped countries. Also, the author used the classification of the countries according to the World Bank.

\subsection{Application of Diffusion Theory for the Smartphone Market}

Diffusion is the approach which explains the acceptance of innovations (or innovative products) by society through the marketing channels (Rogers, 2003). The smartphone brings development to emerging countries and creates an information sharing environment (Baah \& Naghavi, 2018). It increases digital literacy (Spitzer, 2015) and creates information seeking environment which positively affects students and increases their knowledge regarding the specialization (Saxena et al., 2018). However, the topic is open for discussion and some studies contradict the above-mentioned notion. They highlight that, even if smartphone influences consumers/young adults everyday life, proof of the fact is insufficient (Spitzer, 2015). Smartphones have a moderating effect on technology diffusion (Sung, 2016). Nowadays, it is easier to access/purchase the device (IDC, 2017), however, usage of smartphones did not narrow digital divide (Lee et al., 2015; Puspitasari \& Ishii, 2016). The adoption 
of handsets may reduce the digital gap in the case of the young and middle-aged adults (Puspitasari \& Ishii, 2016; Sung, 2016). However, some researches contradict with above-mentioned notions (Reid, 2018; Tsetsi \& Rains, 2017). From the other side, according to Rogers (2003) classification, it conforms closely to adopter categories such as innovators, early adopters, and early majority. Even if the adoption of smartphones is harder in the case of older adults, they considered to be an important segment for smartphone vendors (Hong et al., 2016).

Digital divide becomes stronger under the influence of income inequalities (Abdel-Wahab \& El-Masry, 2011; James, 2014) which keeps some underdeveloped countries out of technological development (Warschauer, 2003). Due to the different endowments, geopolitical situation and historical developmental features, significant social and economic inequalities have emerged in the spatial structure of Europe over the last decades. The dividing line between the former socialist countries (including Hungary) and the EU-15 states is very sharp (Bálint \& Tóth, 2018). In developing countries which can be characterized by high illiteracy, poverty, and underdevelopment, adoption of the devices is not easy (Sam, 2019). Moreover, nowadays industrialized countries reached the overhead of the penetration rate (Abdel-Wahab \& El-Masry, 2011), while sales of handsets and penetration rate gradually increase in emerging economies. Researches analyze the influence of different variables in these countries, however, the above-mentioned provisions have an impact on the general situation and no any marketing tool could be effective in extreme poverty and illiteracy. Diffusion of innovations and technological access in developing countries are connected with economic growth (Rogers, 1976), wealth measured by GDP (Abdel-Wahab \& ElMasry, 2011), and/or public welfare according to Bordenave's (1976) work (as cited in Rogers, 2003, p. 170). Also in emerging economies difference in social status and concentration of main force ("power, economic wealth and information" (Rogers, 2003, p. 170)) in the hand of few individuals poses additional challenges with respect to adoption. In the fifth edition of the "Innovation Diffusion" book, Rogers discussed product development in the case of cellular phones in the subchapter entitled "Cellular Telephones and the Lifestyle Revolution" (Rogers, 2003, p. 302). At the end of the 1990s, the size and price of cellular phones decreased, and the need to be in touch with family and the closest people increased the rate of adoption. Smartphones became fashion and status symbols for consumers according to some author (Rogers, 2003). After 2003, technologies faced significant change, however, over the period, smartphones have already changed the lifestyle of consumers globally (Rogers, 2003). Later, different researchers applied the innovation diffusion theory for mobile phone/smartphone market (López-Nicolás et al., 2008; Roach, 2009). The perceived attribute of innovation as part of the innovation theory was the antecedent variable in the case of the smartphone market in Taiwan (Huang \& Shih, 2017). Moreover, research conducted among respondents from AP, MENA, and Europe also showed that technological facilities have a positive outcome on the perception of innovativeness (Kim, 2016). This study is aimed to define whether there is a relationship between smartphone diffusion indicators and income level worldwide and in the case of developing countries, and measured the strength of the relationship in each case.

\subsection{Factors and variables influencing the smartphone market}

Income level is a categorical variable assigned by the World Bank each year (World Bank Database, 2018). Mainly it is used to compare the economic situation and poverty level in different counties (Fig. 1). Income level is measured by using per capita GNI in the World Bank's Atlas method (World Bank, 2018). In the current paper, the income level was applied to express the economic strength of the country, the purchasing power of smartphones and the effect of income on diffusion. In the case of smartphone purchasing power, income level is an essential variable to assume the chance of the consumers to buy a better/expensive model of the device. In marketing literature, the income level is used as an independent variable. In different studies regarding smartphone purchase, income level is used on micro level (Karakaş \& Öztürk, 2016; Shabrin et al., 2017), however, it was implemented on macro level in order to analyze the level of ICT/mobile phone diffusion in developing countries (Abdel-Wahab \& El-Masry, 2011; James, 2012).

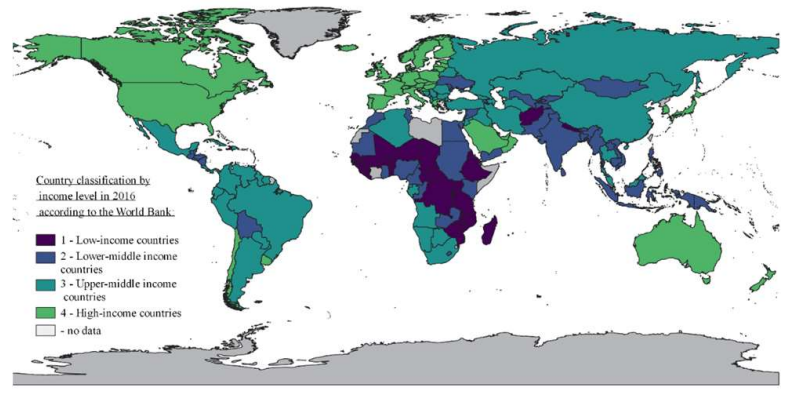

Fig. 1. Country classification by income level in 2016 by applying QGIS version $3.4 .3^{1}$ Source: Own editing based on income classification of the World Bank

\footnotetext{
${ }^{1}$ According to the result of Summary Independent-Samples T Test, country classification by income level from 2016 considered to be the same with the country classification according to the rounded arithmetic mean of 5 years $(2013-2017)$ with $95 \%$ confidence level $(t(374)=-4.329 p=0.00)$.
} 
Mobile-cellular subscription is an indicator which aims to measure quantity and level of mobile phone diffusion on macroeconomic level (Abdel-Wahab \& El-Masry, 2011; Aker \& Mbiti, 2010; Donner \& Jonathan, 2009). Basically, they applied to compare mobile phone penetration and diffusion. However, the market share of iOS and Android-based smartphones create a picture of the smartphone market, consumer preferences, and sales. In previous researches, authors support the idea that Android is more widespread as consumers are able to install and use more applications (Unno \& Xu, 2013; Wang et al., 2017), yet different screen size and other features create some problems for application developers (Hsieh et al., 2017). Competition among smartphone operational systems (Tseng et al., 2014), choice of the poor consumers in developing countries (Karippacheril et al., 2013), the influence of OS to personality (Reid, 2018) was analyzed deeply. The mobile leapfrogging (James, 2016; Puspitasari \& Ishii, 2016) created problems not only for developing countries but also in science. The main problem of the industry was that all analyses involved overall mobile phone market, not a specific product group and cases from different emerging countries were analyzed. In the last few years, the situation has changed significantly, and now it is easier to see changes and general trends of the smartphone market in the world. Scientists have shown the importance of the income in smartphone diffusion, and the digital divide at the microeconomic level. In the above-mentioned papers, assumptions were tested by applying questionnaire surveys and income was used in combination with demographic variables. Moreover, no any research about analyzing tendencies in the smartphone at the macroeconomic level was found. The aim of the study is to fill the gap by investigating the level of moderating effect of income on smartphone diffusion at the country level. Additionally, the above-mentioned works concentrated on mobile phone diffusion were analyzed using a time frame. However, in the current study, we focused especially on the dependence of smartphone diffusion on income level, and, for this purpose, arithmetic mean of 5 years (from 2013 to 2017) and separately for the data of 2016 were used as indicators.

\section{Methodology}

\subsection{Research objectives and research questions}

Current study has confirmatory characteristics, linked with the huge impact of technology diffusion on income level. However, the strength of the relationship can be a matter of discussion. Regarding the below-mentioned notion, there are two main objectives of the research. First is to define whether there is a relationship between income and smartphone market indicators all over the world and in developing countries (according to the World Bank classification, higher-middle income, lowermiddle income, and low-income countries). Second is to measure the effect of income on smartphone diffusion in both cases. Based on the objectives, research questions are the following:

$\checkmark$ How important is the income level in smartphone diffusion all over the world and in developing countries?

$\checkmark \quad$ Is there any difference between smartphone diffusion strength in the world and developing economies?

\subsection{Research design}

According to the aim of the research, statistical analyses were conducted in two stages. In the first stage, countries were divided into four groups using the Hierarchical Cluster Analysis (Ward's method). Several variables representing the smartphone market (iOS market share, Android market share, mobile subscription) were used for classifying countries into groups. In the current case, mobile cellular phone subscription could be accepted as a quantity of sold devices per 100 inhabitants while Android and iOS market share as the representations of smartphone OS per 100 users. Ward's method is a Hierarchical Clustering algorithm aimed to combine groups with few numbers of observations together which results in almost equal cluster membership (Cleff \& Cleff, 2013, p. 442; Everitt et al., 2011, p. 83). Also, it is important to note that, this method of clustering is sensitive to outliers (Brian S. Everitt, 2005). The main reason for generating four groups by applying Ward's method was to create almost equal clusters membership and making an easy comparison between income and smartphone market. Classification according to income level and smartphone market indicators were illustrated by using QGIS software version 3.4.3 (QGIS Development Team, 2018).

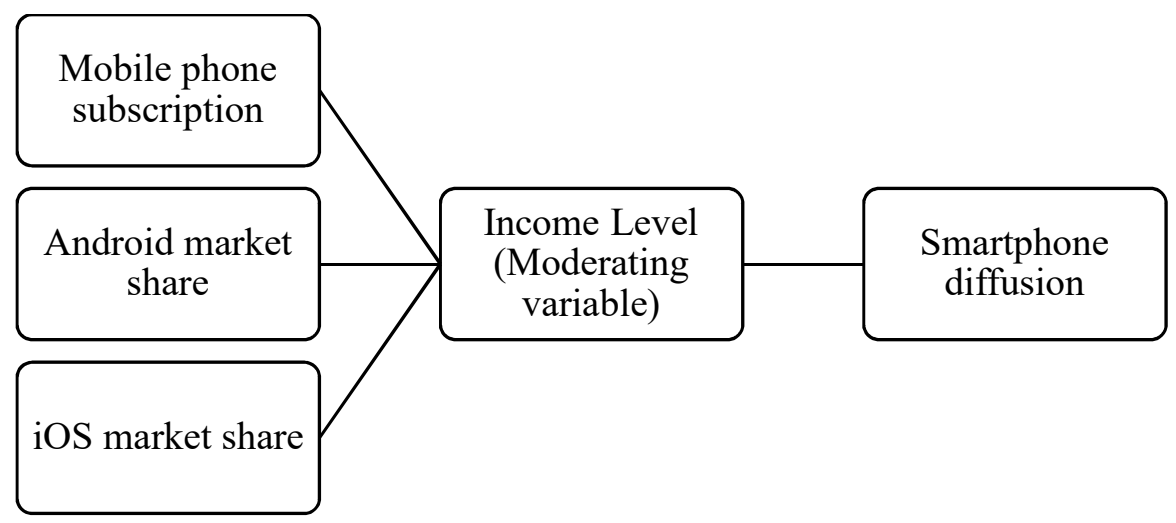

Fig. 2. Research model 
Chi-square test of independence is designed for defining the relationship between two categorical variables (Cunningham et al., 2016; Gravetter \& Wallnau, 2014). Two main assumptions for applying the test are large sample size and independence of variables (Cunningham et al., 2016). In the second stage, the results of the Hierarchical Cluster Analysis were applied as one of the variables in Chi-square analysis. The first variable of Chi-square test was the income level classified by the World Bank. The World Bank splits countries into four income groups using GNI - high, upper-middle, lower-middle, and low each year. The second variable was the output of Ward's method. As a result, the impact of income on the smartphone market and strength of relationship would be measured for finding the answers to the research question.

\subsection{Data collection}

The main aim of the paper was to define whether there was any relationship between income level measured by GNI and smartphone diffusion or not. Therefore, data were collected from different statistical sources (Table 1) and indicators were analyzed using the SPSS statistical data editor version 23.0 (IBM Corp., 2015). Countries (188 countries) listed in annual ITU reports were included in the research. Firstly, data from 2016 was analyzed. In this case, economic changes as macroeconomic fluctuations, the dependence of some countries on oil export/prices, currency devaluations and cyclic and/or seasonal fluctuations, political instability, etc. might affect the results of the study. For achieving actual results with reducing external effects, data from 2013 to 2017 were collected and the arithmetic mean of 5 years calculated. All analyses were conducted in the same way and compared with results of 2016. The calculation of arithmetic mean made it possible to reduce the impact of external factors on the numbers/smartphone market indicators.

Table 1

Descriptive Statistics

\begin{tabular}{|c|c|c|c|c|c|c|c|c|}
\hline Variables & $\mathrm{N}$ & Missing & Mean & Std. Deviation & Minimum & Maximum & Source & $\begin{array}{c}\text { Accessed and } \\
\text { downloaded }\end{array}$ \\
\hline $\begin{array}{l}\text { Mobile cellular subscription per } \\
100 \text { inhabitants } 2016\end{array}$ & 186 & 2 & 107.00 & 39.50 & 10.21 & 240.80 & ITU & $8 / 1 / 2019$ \\
\hline Android market share 2016 & 187 & 1 & 71.55 & 11.39 & 37.72 & 94.47 & Statista & $8 / 1 / 2019$ \\
\hline iOS market share 2016 & 176 & 12 & 16.11 & 13.82 & 0.35 & 59.98 & Statista & $8 / 1 / 2019$ \\
\hline Income level 2016 & 188 & 0 & 2.72 & 1.05 & 1.00 & 4.00 & $\begin{array}{l}\text { World } \\
\text { Bank }\end{array}$ & $8 / 1 / 2019$ \\
\hline $\begin{array}{l}\text { The arithmetic mean of Mobile cel- } \\
\text { lular subscription during 2013- } \\
2017 \text { (per } 100 \text { inhabitants) }\end{array}$ & 188 & 0 & 104.46 & 37.74 & 9.11 & 238.76 & ITU & $8 / 1 / 2019$ \\
\hline $\begin{array}{l}\text { The arithmetic mean of Android } \\
\text { market share during 2013-2017 }\end{array}$ & 188 & 0 & 61.47 & 11.60 & 33.00 & 90.35 & Statista & $8 / 1 / 2019$ \\
\hline $\begin{array}{l}\text { The arithmetic mean of iOS market } \\
\text { share during } \\
2013-2017\end{array}$ & 188 & 0 & 17.11 & 14.56 & 0.88 & 64.80 & Statista & $8 / 1 / 2019$ \\
\hline $\begin{array}{l}\text { Rounded arithmetic mean of in- } \\
\text { come level during } \\
2013-2017\end{array}$ & 188 & 0 & 2.26 & 1.01 & 0.00 & 4.00 & $\begin{array}{l}\text { World } \\
\text { Bank }\end{array}$ & $8 / 1 / 2019$ \\
\hline
\end{tabular}

Source: Own editing based on SPSS output

\section{Results and Discussion}

\subsection{Hierarchical Cluster Analysis (Wards method)}

Nowadays cluster analysis is one of the most frequently used statistical tools in marketing. The main aim of cluster analysis is to group the observed elements and to see the difference between the level of the impact of different variables. Cluster analysis in the smartphone market is mainly used for summarizing results of a survey (Petrovčič et al., 2018; Sidorchuk et al., 2018). Ward's method (Squared Euclidian Distance) was chosen as a clustering method according to marketing literature as it creates approximately equal sized clusters. (Dolcinar, 2003). In the current study, several variables were used for creating clusters: mobile cellular subscription and iOS/Android market share. Mobile-cellular phone subscription is the common variable as it expresses the level of mobile phone diffusion per 100 inhabitants (James, 2016). However, iOS and Android market share create a picture of purchased smartphones and provides some information related to the economic situation of the country (Baah \& Naghavi, 2018; GSMA, 2017). Applying four groups in cluster analysis gives an opportunity to compare the results of cluster analysis with income level and define interconnection. In order to have more relevant outcomes, extreme high and low values should have been excluded from further research. However, it would cause a significant loss of information. For this reason, data were not deleted from the analysis. It is important to mention that extreme cases are the poorest or the richest countries.

According to the results of 2016, the first cluster represents data about 25 underdeveloped countries in extreme poverty conditions which are far from technological development (Fig. 3). Mostly these are African and some Asian countries. The second cluster includes part of Europe, Northern and partially South America, Australia and several countries from Africa. It is important to mention that well-developed countries were listed in the cluster. The third cluster consists of Post-Soviet (well known as CIS) and quite a few European, also some African and South American states. Overall, it consists of 53 countries 
worldwide. The second and the third cluster altogether mainly combines higher-middle and high-income group countries. Last, the fourth group is characterized by underdeveloped African, Asian and few South American countries.

Results of cluster analysis according to the arithmetic mean of 5 years differ from the results of the same analysis from 2016. The first cluster contains mostly the developing countries with low, lower-middle and upper-middle income. Overall, 73 countries were included in the first group and only Andorra represents high-income countries. However, high-income countries tend to dominate in the second cluster. These are mainly Western European countries complemented by several Northern American and Asian countries. Only one upper-middle income (Albania) and few lower-middle income countries were involved in the cluster. The third group almost includes the same countries as it is illustrated in the results from 2016.50 countries were added into the cluster. The fourth cluster includes some European, South American and African countries.

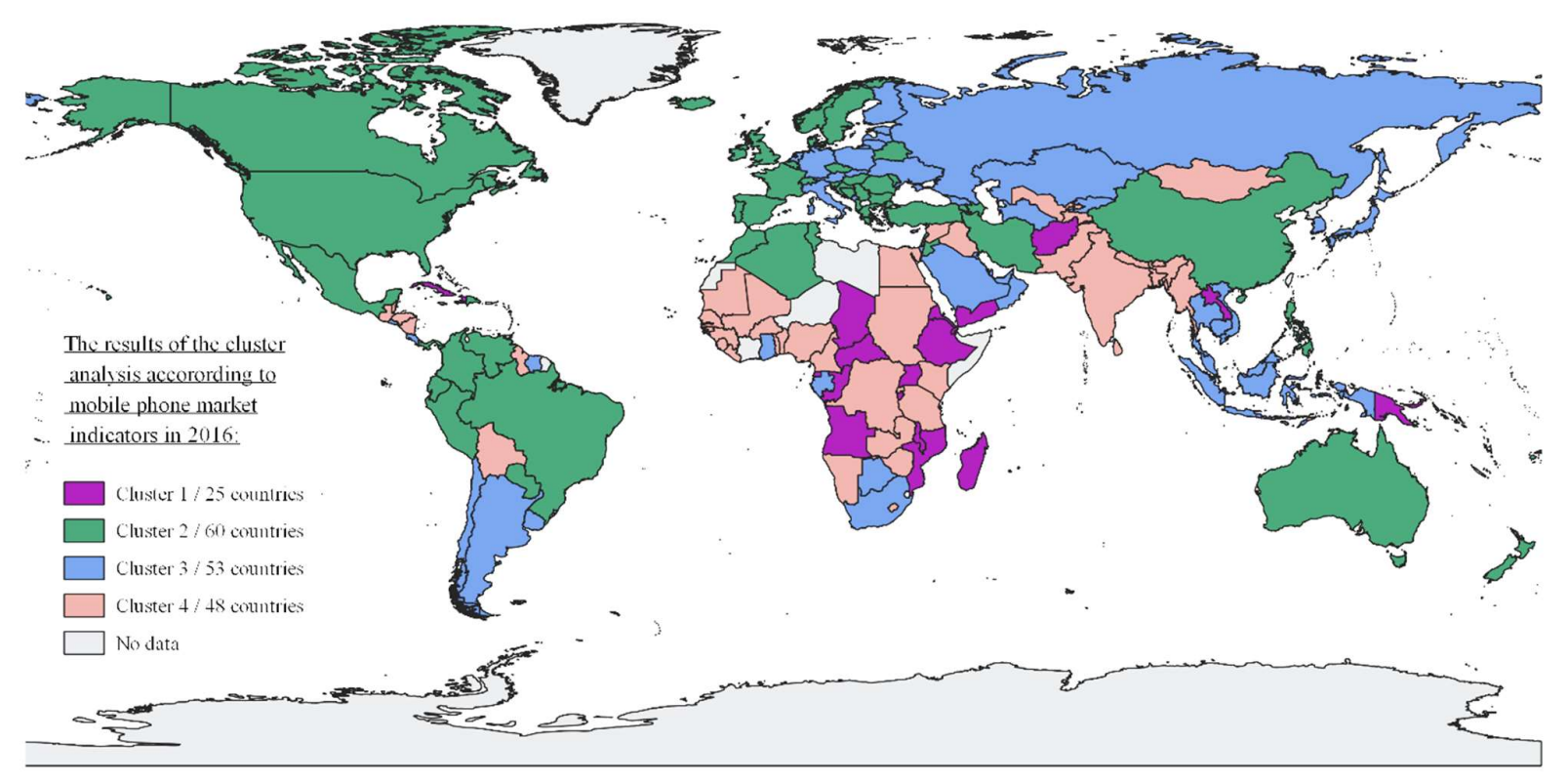

Fig. 3. The results of the cluster analysis according to smartphone market indicators 2016

Source: own editing based on Hierarchical Cluster Analysis

\subsection{Chi-square test of independence}

Chi-square test of independence is designed for comparing and summarizing information related to different groups/categorical variables based on a comparison of the frequency distribution (Field, 2013). Hence, it is an irreplaceable tool in marketing as it defines that two variables are independent or there is a relationship between them (Everitt, 2005). In order to understand interdependencies in the smartphone market, the result of cluster analysis was compared with a key variable - income. So, the hypothesis stated as follows:

$\mathrm{H}_{0}$ : Worldwide, there is no relationship between income level and smartphone choice.

$\mathrm{H}_{1}$ : Worldwide, smartphone market depends on the income level of the country.

$\mathrm{H}_{2}$ : In developed countries, the smartphone market dependency on income level is higher.

Generally, the significance level of alpha (the $\alpha$ ) for social science is accepted as 0.05 . The degree of freedom was 9 according to results of the Chi-square test $(\alpha=0.05, \mathrm{df}=9)$ in 2016. Following the results of 2016, it was evident that $\mathrm{H}_{0}$ was rejected. So, there was a relationship between income level and smartphone market variables $\left(\chi^{2}(9, n=187)=81.824 ; p<0.05\right)$ in the mentioned year. Based on the results, it can be concluded that there was a relationship between income level and smartphone market indicators. The results of Chi-square test was significant and only one cell had expected value less than 5 which is $6.3 \%$. According to the statistical literature, the result of the test is only valid if the expected count is under $25 \%$ (George \& Mallery, 2016, p. 129), and results of the current study complied with the requirements. Generally, phi-coefficient is used for measuring correlation, yet in Chi-square test, it is calculated by two-dimensional data matrix proportion (Gravetter \& Wallnau, 2014, p. 532). For the current study, it was impossible to apply it, as each variable had four categories. Moreover, Cramer's $\mathrm{V}$ known as strength of the association is 0.382 which was also significant. The indicator usually varies between 0 and 1 
which also usually explains in the same way as correlation. (Gravetter \& Wallnau, 2014, p. 532). However, the results of the same analysis according to the arithmetic mean of 5 years showed only a slight variance from original (2016) results. $\mathrm{H}_{0} \mathrm{was}$ rejected in the same way and there was overall connection between the income level of countries and smartphone indicators $\left(\chi^{2}(12, n=188)=71.274 ; p<0.05\right)$. Strength of the relationship was moderate and no any cell had expected value less than 5 . The result of Cramer's V/strength of the association was lower than in 2016 , and it is 0.355 . It is considered as the moderate association between variables.

In the second stage, developed or high-income countries were deleted from the analysis. The main aim was to compare the results and to observe clear tendencies in the smartphone market in emerging economies and prove/reject $\mathrm{H} 2$. Before conducting the research, the strength of relationship expected to be high in the developing countries and it would prove confirmatory characteristics of the study. Main arguments supporting the notion were: social importance (Persaud \& Azhar, 2012) and self-expressive/fashion value (Kımıloğlu et al., 2010; Reid, 2018) of the device, increasing penetration and subscription rates (James, 2016), and price sensitivity of consumers from developing countries (James, 2016). It might be logical; however, results did not meet expectations.

Results of Chi-square test for 2016 also show significance $\left(\chi^{2}(4, n=132)=23.761 ; p<0.05\right)$, however, numbers were lower in comparison with the first analysis. Cramer's V was 0.3 which seems to be surprising. It means that the second hypothesis can be partly accepted, as smartphone diffusion does not strongly depend on the income level in developing countries in 2016. To verify the accuracy of the above-mentioned result, the same analysis run by using the arithmetic mean of 5 years. The result of analysis was significant $\left(\chi^{2}(4, n=136)=26.197 ; p<0.05\right)$, however, strength of association was only 0.31 . It strengthened the assumption that in the developing world, during the mentioned period smartphone diffusion depended on income at a weak level. Income did not seem to be the key indicator of smartphone diffusion in the developing world.

If the strength of the relationship will be compared worldwide and in developing countries (worldwide/developing $0.382 / 0.3$ in 2016; $0.355 / 0.31$ based on the arithmetic mean of 5 years), worldwide smartphone indicators have an association in a medium level. It means that worldwide and especially in developed countries smartphone purchase depended on income level. Statistically, stronger relationship in developed economies caused some increase in numbers worldwide. Additionally, in the countries considered as low and lower-middle income countries, there is untracked and/or informal money flow which was not taken into account by the World Bank or other international organizations (Sullivan, 2007). So, numbers which are included in the analysis might not reflect the real situation and the results would be incompatible with current circumstances.

Smartphone diffusion is weakly influenced by income in developing countries. The moderating effect of income during 20132017 cannot be considered to be more than 30\%. So, the impact of the other factors/attributes (Rogers, 2003) on smartphone purchase/adoption is considerably high. Also, demographic aspects (Lee et al., 2015) and education (Sung, 2016) may affect smartphone diffusion and widen the smartphone gap. Results prove innovation diffusion curve offered by Rodgers (2003) is compatible with the current situation in the smartphone market and even if poverty (according to income level) influenced (James, 2016) the smartphone market, the impact is significantly low.

\section{Conclusion}

Smartphones are portable devices which have plenty of functions to make life easy and comfortable. During the last decade competition in the smartphone market was strong, and it influenced not only the average price (IDC, 2017) but also quantity of produced handsets (GSMA, 2017). Average Android smartphone's price gradually decreased since 2008 at least two times (IDC, 2017), and the penetration rate has increased year by year (Baah \& Naghavi, 2018). So, for normal goods, demand had to be increased in the current situation. Logically, in the same economic conditions, according to the income elasticity of demand (the price decreases and income is the same) consumers were able to purchase two times more devices. However, in developing countries, the strength of the relationship between income and mobile phone subscription did not prove the abovementioned idea. Consequently, high-tech products such as smartphones cannot be considered as normal goods, influenced by Supply and Demand Law.

Smartphone purchase all over the world depends on income at a moderate level. In the case of developing countries, although the association was expected to be stronger, it is weak. It means that income has a positive moderating effect on smartphone diffusion, however strength of the effect is not so significant. Developed countries caused stronger association worldwide which means that if the analysis would be conducted only for developed countries, there would be strong or at least moderate relationship between variables guaranteed. The results proved the difference in innovation diffusion speed as it was illustrated by Rogers (2003). The purchase of a smartphone is not highly dependent on income, it is a complex decision connected more with a lot of factors.

\section{Limitations and Further Research}

All data included in the research express the macroeconomic situation of the year 2016 and arithmetic mean of 5 years (from 2013 to 2017). In the case of developing countries, we faced difficulties with the access to data. This is the main reason why data from 2018 could not be used. However, some variables are not included in the study, as data from a lot of countries were missing which would decrease sample size significantly. Lack of information about smartphone market creates additional 
difficulties. For example, it was impossible to reach information about smartphone subscription all over the world, so mobile phone subscription was used together with the market share of iOS and Android.

Nevertheless, not only income is a key indicator in terms of the smartphone market, handset purchase and use. There is a big potential in applying quantitative analysis techniques for measuring differences in purchase and usage behavior in terms of neighboring countries. The output of cluster analysis based on smartphone indicators shows the territorial/regional effect of neighboring countries on the market. It means that mostly the neighbor countries belong to the same groups. For current purposes, the territorial effect was used as a combination of the social, cultural, economic and technical influence of countries on each other. There are some exceptions like countries such as Afghanistan, Lao PDR, etc. with extremely low values which were not excluded from analysis as per the aim of the paper. It is planned to continue research by the involvement of general macro-economic indicators as factors influencing smartphone sales and to analyze the neighboring effect by tools such as territorial autocorrelation.

\section{References}

Abdel-Wahab, A. G., \& El-Masry, A. A. A. (2011). Mobile information communication technologies adoption in developing countries: Effects and implications. https://doi.org/https://doi.org/10.4018/978-1-61692-818-6

Aker, J. C., \& Mbiti, I. M. (2010). Mobile phones and economic development in Africa. Journal of Economic Perspectives, 24(3), 207-232.

Ann, B. Y., Chen, C. M., \& Liu, H. M. (2017). Product Attributes and Purchase Intention for Smartphones: A Moderated Mediation Model. International Journal of Mobile Communications, 16(1), 1.

Baah, B., \& Naghavi, N. (2018). Beyond the basics: How smartphones will drive future opportunities for the mobile money industry. Retrieved from www.gsma.com/mobilemoney

Brian S. Everitt, D. C. H. (2005). Encyclopedia of Statistics in Behavioral Science. https://doi.org/10.1002/9781118445112.stat06304

Bálint, C., \& Tóth, T. (2018). Comparison of Hungary and the EU-28 countries in terms of health situation with special regard to chronic morbidity 14th Annual International Conference on Economics and Business, (January 2019).

Bringula, R. P., Moraga, S. D., Catacutan, A. E., Jamis, M. N., \& Mangao, D. F. (2018). Factors influencing online purchase intention of smartphones: A hierarchical regression analysis. Cogent Business and Management, 5(1), 1-18.

Cleff, T., \& Cleff, T. (2013). Univariate Data Analysis (7th editio). https://doi.org/10.1007/978-3-319-01517-0_3

Coelho, D. C., Meneses, R. F. C., \& Moreira, M. R. A. (2013). Factors influencing purchase intention of private label products: The case of smartphones. International Conference on Exploring Services Science, 313-321.

Cunningham, J. B., \& James O. Aldrich. (2016). Summary for Policymakers. In Climate Change 2013 - The Physical Science Basis (2nd editio, Vol. 2). https://doi.org/10.1017/CBO9781107415324.004

Dolcinar, S. (2003). Using Cluster Analysis for Market Segmentation - Typical Misconceptions, Established Methodological Weaknesses and Some Recommendations for Improvement. Australasian Journal of Market Research, 11(2), 5-12.

Donner, R., \& Jonathan, L. (2009). Mobile Communication. In New Directions in Folklore. Polity Press.

Everitt, B. S., Landau, S., Leese, M., \& Stahl, D. (2011). Cluster Analysis (5th editio). https://doi.org/10.1007/BF00154794

Field, A. (2013). Discovering statistics using IBM SPSS statistics (Fourth edi; M. Carmichael, Ed.). SAGE Publications Ltd.

George, D., \& Mallery, P. (2016). IBM SPSS statistics 23 step by step: A simple guide and reference. Routledge.

Gravetter, F. J., \& Wallnau, L. B. (2014). Essentials of the statistics for the behavioral science. In Learning ( $8^{\text {th }}$ ed.).

Groß, M. (2015). Exploring the acceptance of technology for mobile shopping: an empirical investigation among Smartphone users. International Review of Retail, Distribution and Consumer Research, 25(3), 215-235.

GSMA. (2017). Accelerating affordable smartphone ownership in emerging markets. Retrieved from https://www.gsma.com/

GSMA Intelligence. (2019). The Mobile Economy $2019 . \quad$ Retrieved from https://www.gsmaintelligence.com/research/?file=b9a6e6202ee1d5f787cfebb95d3639c5\&download

Haskell, B. (2004). Portable Electronics Product Design and Development (p. 384). p. 384. McGraw-Hill Professional.

Hong, S. G., Trimi, S., \& Kim, D. W. (2016). Smartphone use and internet literacy of senior citizens. Journal of Assistive Technologies, 10(1), 27-38. https://doi.org/10.1108/JAT-03-2015-0006

Hooi Ting, D., Fong Lim, S., Siuly Patanmacia, T., Gie Low, C., \& Chuan Ker, G. (2011). Dependency on smartphone and the impact on purchase behaviour. Young Consumers, 12(3), 193-203.

Hsieh, C., Chiu, C. M., Hsu, T. P. L. C. Y. L., Liang, T. P., \& Lai, C. Y. (2017). Factors affecting satisfaction and brand loyalty to smartphone systems: A perceived benefits perspective. International Journal of Mobile Communications, 16(1), 1 .

Huang, Y. T., \& Shih, K. H. (2017). Customer-based brand equity of smartphone in the emerging market. International Journal of Mobile Communications, 15(5), 467.

IBM Corp. (2015). IBM SPSS Statistics for Windows, Version 23.0. Armonk, NY: IBM Corp.

IDC. (2017). Worldwide Mobile Phone Tracker, 2017. Boston, MA.

ITU. (2018). ITU releases 2018 global and regional ICT estimates. Retrieved April 2, 2019, from https://www.itu.int/en/mediacentre/Pages/2018-PR40.aspx

James, J. (2012). The ICT Development Index and the digital divide: How are they related? Technological Forecasting and Social Change, 79(3), 587-594. 
James, J. (2014). Patterns of mobile phone use in developing countries: Evidence from Africa. Social Indicators Research, $119(2), 687-704$.

James, J. (2016). The impact of mobile phones on poverty and inequality in developing countries. https://doi.org/https://doi.org/10.1007/978-3-319-27368-6

Jamalova, M., \& Constantinovits, M. (2019). The Comparative Study of the Relationship Between Smartphone Choice and Socio-Economic Indicators. International Journal of Marketing Studies, 11(3), 11.

Karakaş, G., \& Öztürk, D. (2016). Analysis of the Factors Affecting the Mobile Phone Purchasing Decisions of University Students in Turkey City of Ordu Example. Journal of Life Economics, 3(1), 23-42.

Karippacheril, T. G., Nikayin, F., De Reuver, M., \& Bouwman, H. (2013). Serving the poor: Multisided mobile service platforms, openness, competition, collaboration and the struggle for leadership. Telecommunications Policy, 37(1), 2434.

Kim, J. S. (2016). An Investigation of Key Factors Affecting the Adoption of Smartphone in Three Regions. International Journal of Innovation and Technology Management, 13(06), 1640017.

Kımıloğlu, H., Nasır, V. A., \& Nasır, S. (2010). Discovering behavioral segments in the mobile phone market. Journal of Consumer Marketing, 27(5), 401-413.

Lee, H. J., Park, N., \& Yongs. (2015). A new dimension of the digital divide: Exploring the relationship between broadband connection, smartphone use and communication competence. Telematics and Informatics, 32(1), 45-56.

Liao, C. H., \& Hsieh, I. Y. (2013). Determinants of consumer's willingness to purchase gray-market smartphones. Journal of Business Ethics, 114(3), 409-424.

López-Nicolás, C., Molina-Castillo, F. J., \& Bouwman, H. (2008). An assessment of advanced mobile services acceptance: Contributions from TAM and diffusion theory models. Information \& Management, 45(6), 359-364.

Mohammed, A. B. (2018). Selling smartphones to generation Z: Understanding factors influencing the purchasing intention of smartphone. International Journal of Applied Engineering Research, 13(6), 973-4562.

Persaud, A., \& Azhar, I. (2012). Innovative mobile marketing via smartphones: Are consumers ready? Marketing Intelligence and Planning, 30(4), 418-443.

Petrovčič, A., Slavec, A., \& Dolničar, V. (2018). The ten shades of silver: Segmentation of older adults in the mobile phone market. International Journal of Human-Computer Interaction, 34(9), 845-860.

Potnis, D. (2016). Inequalities creating economic barriers to owning mobile phones in India: Factors responsible for the gender digital divide. Information Development, 32(5), 1332-1342.

Puspitasari, L., \& Ishii, K. (2016). Digital divides and mobile Internet in Indonesia: Impact of smartphones. Telematics and Informatics, 33(2), 472-483.

QGIS Development Team. (2018). QGIS Geographic Information System. Retrieved from http://qgis.org

Reid, A. J. (2018). Smartphone Paradox. https://doi.org/https://doi.org/10.1007/978-3-319-94319-0_

Roach, G. (2009). Consumer perceptions of mobile phone marketing: A direct marketing innovation. Direct Marketing, 3(2), 124-138.

Rogers, E. M. (1976). Communication and development: The passing of the dominant paradigm. Communication Research, 3(2), 213-240.

Rogers, E. M. (2003). The diffusion of innovation (5th ed.). https://doi.org/https://doi.org/10.1002/jps.2600520633

Sam, S. (2019). Bridging the Digital Gap in Sub-Saharan Africa. In M. Ragnedda \& B. Mutsvairo (Eds.), Mapping Digital Divide in Africa (pp. 215-256). https://doi.org/10.2307/j.ctvh4zj72.15

Saxena, P., Gupta, S. K., Mehrotra, D., Kamthan, S., Sabir, H., Katiyar, P., \& Sai Prasad, S. V. (2018). Assessment of digital literacy and use of smart phones among Central Indian dental students. Journal of Oral Biology and Craniofacial Research, 8(1), 40-43.

Shabrin, N., Khandaker, S., Bin, S., Kashem, A., Hie, C. K., \& Susila, T. (2017). Factors Affecting Smartphone Purchase Decisions of Generation-Y. The Journal of Contemporary Issues in Business and Government, 23(1), 47-65.

Sidorchuk, R., Mkhitaryan, S. V., Musatov, B. V., Meshkov, A. A., \& Tultaev, T. A. (2018). The influence of high level values on brand preferences of student youth in Russia. International Journal of Retail and Distribution Management, 46(7), 638-656.

Spitzer, M. (2015). M-Learning? When it comes to learning, smartphones are a liability, not an asset. Trends in Neuroscience and Education, 4(4), 87-91.

Sullivan, N. P. (2007). You can hear me now: how microloans and cell phones are connecting the world's poor to the global economy. https://doi.org/https://doi.org/10.5860/choice.45-3313

Sung, W. (2016). A study of the digital divide in the current phase of the information age: The moderating effect of smartphones. Information Polity, 21(3), 291-306.

Tseng, F. M., Liu, Y. L., \& Wu, H. H. (2014). Market penetration among competitive innovation products: The case of the Smartphone Operating System. Journal of Engineering and Technology Management - JET-M, 32, 40-59.

Tsetsi, E., \& Rains, S. A. (2017). Smartphone Internet access and use: Extending the digital divide and usage gap. Mobile Media and Communication, 5(3), 239-255.

Uddin, M. R., Zahan Lopa, N., \& Md, O. (2014). Factors Affecting Customers' Buying Decisions of Mobile Phone : A Study on Khulna City, Bangladesh. International Journal of Managing Value and Supply Chains, 5(2), 21-28.

Unno, M., \& Xu, H. (2013). Optimal platform strategies in the smartphone market. Electronics and Communications in Japan, 96(7), 1-10. 
1150

Wang, Y., Vasilakos, A., Jin, Q., \& Zhu, H. (2017). Smartphone-Based Human Activity Recognition. In Device-to-Device based Proximity Service. https://doi.org/10.1201/9781315120201-9

Warschauer, M. (2003). Technology and social inclusion. https://doi.org/10.1017/cbo9781107300910.004

World Bank. (2008). Global economic prospects: Technology diffusion in the developing world. https://doi.org/https://doi.org/10.1596/978-0-8213-7365-1

World Bank. (2018). New country classifications by income level. Retrieved April 9, 2019, from https://blogs.worldbank.org/opendata/new-country-classifications-income-level-2018-2019

World Bank Database. (2018). World Development Indicators. Retrieved from https://data.worldbank.org/

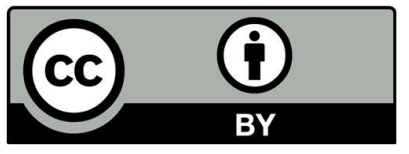

(C) 2020 by the authors; licensee Growing Science, Canada. This is an open access article distributed under the terms and conditions of the Creative Commons Attribution (CC-BY) license (http://creativecommons.org/licenses/by/4.0/). 